\title{
Oral Cavity Neoplasm
}

National Cancer Institute

\section{Source}

National Cancer Institute. Oral Cavity Neoplasm. NCI Thesaurus. Code C7606.

A benign or malignant neoplasm that affects the oral cavity. 